\title{
EBF1 Gene
}

National Cancer Institute

\section{Source}

National Cancer Institute. EBF1 Gene. NCI Thesaurus. Code C80023.

This gene plays a role in transcriptional activation. 